\title{
De la noematologie la hermeneutică. Perspectiva lui Nicolae I. Apostolescu
}

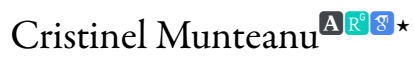 \\ Facultatea de Comunicare și Relații Internaționale, Universitatea „Danubius”, Bd. Galați 3, 800654 Galați, România
}

\section{Despre articol}

Istoric:

Primit 17 octombrie 2020

Acceptat 13 noiembrie 2020

Publicat 27 decembrie 2020

Cuvinte-cheie:

noematologie

hermeneutică

sens

etimologie populară

lingvistica textului

\begin{abstract}
Rezumat
În acest articol voi analiza contribuția unui discipol al lui B. P. Hasdeu, Nicolae I. Apostolescu, care (în studiul Limbajul și înfạțişările lui sociale) reia discuția magistrului său despre noematologie și lărgește sfera acesteia, ducînd-o spre un soi de „hermeneutică a sensului”, aplicabilă atît la revelarea sensului (ascuns) din artă în general, cît și la explicațiile de natură etimologică (pentru a lămuri, de pildă, felul în care apar etimologiile populare, cînd vorbitorul face anumite legături, „înțelege” într-un anume fel situațiile care motivează anumite semnificații ș.a.m.d.). Cu acest prilej, voi încerca să demonstrez că N.I. Apostolescu merită să fie considerat un precursor însemnat al cercetărilor hermeneutice din spațiul românesc.
\end{abstract}

\section{Preliminarii}

De știința noematologiei m-am ocupat pe larg cu diverse ocazii: o dată, într-un articol intitulat Noematologia lui B. P. Hasdeu: o anticipare a skeologiei lui E. Coșeriu (avînd la bază o comunicare din 2013) și, a doua oară, mult mai amănunțit, în studiul meu introductiv la volumul B. P. Hasdeu, Studii de știința limbii [Institutul European, Iași, 2013] (v. Munteanu, 2013, p. 85-94; Hasdeu, 2013, p. 58-85). Fără a trata chestiunea în detaliu, mă mai referisem la noematologia lui Hasdeu, în raport cu unele idei coșeriene, în 2007 și în 2011 (v. Munteanu, 2007, p. 40; 2011a, p. 32 și 2012a, p. 356). Informațiile descoperite recent mă obligă să revin asupra subiectului, mai ales că acestea îmi confirmă astăzi ${ }^{1}$ unele supoziții pentru a căror verificare textul hasdeian singur nu îmi oferise suficiente dovezi. Este vorba despre contribuția unui discipol al lui Hasdeu, Nicolae I. Apostolescu, care, cel puțin în privința noematologiei, a reușit să-și depășească magistrul, mergînd-aşa cum se și cuvenea-cu Hasdeu dincolo de Hasdeu.

Pentru început, voi reaminti ce este noematologia. Într-un studiu scurt și foarte dens-Un nou punct de vedere asupra ramificațiunilor gramaticei comparative (publicat în primul număr din 1882 al revistei „Columna lui Traian”)-B.P. Hasdeu propunea printre disciplinele gloticii (ori ale gramaticii comparative) și știința noematologiei: „o doctrină separată pentru ceea ce Bréal a numit atît de bine «idei latente»; o doctrină căreia, în lipsă de alt termen, noi îi vom zice noematologie, de la vón $\mu \alpha$ «cugetare intențională»" (Hasdeu, 2013, p. 131). Totodată, Hasdeu sublinia și însemnătatea disciplinei respective, discutînd despre ea la modul superlativ („,această importantisimă doctrină a subînțelegerii”).

Ca termen științific (aparţinînd lingvisticii), neologismul noematologie a fost inventat și utilizat pentru prima dată, în mod sigur, de către Hasdeu. Altminteri, cea mai veche atestare a cuvîntului cu pricina pare a fi în cartea (de beletristică) a scriitorului britanic Arthur Benoni Evans, Fungusiana or the Opinions and Table Talk of Barnaby Fungus (din 1809), însă, în acest caz, noematology are o accepție foarte vagă, desemnînd

*Adresă de corespondență: munteanucristinel@yahoo.com.

${ }^{1}$ Precizez că acest text (în versiunea sa românească) reproduce în formă revizuită, cu unele adăugiri esențiale, articolul meu Din nou despre noematologie: contribuția lui Nicolae I. Apostolescu, publicat în „Limba română” (Chișinău), anul XXIV, nr. 5, 2014, p. 78-93. 
doar gîndurile și opiniile personajului principal. Mai aproape de zilele noastre, termenul noematologie a ajuns să fie întrebuințat mai ales în exegeza referitoare la fenomenologia lui Husserl (v. Rother, 2005, p. 205-310). Despre alte accepții și utilizări ale acestui termen pe terenul lingvisticii am discutat într-un studiu aparte dedicat omonimiei terminologice (v. Moroianu \& Munteanu, 2016, p. 211-213).

\section{Formularea unei ipoteze}

Reîntorcîndu-mă la Nicolae I. Apostolescu, sînt dator să precizez care erau supozițiile mele anterioare despre teoria lui Hasdeu a căror confirmare am găsit-o abia la discipolul său. Pentru aceasta, cer îngăduința cititorilor de a reproduce un lung citat din partea finală a articolului în care am comparat noematologia hasdeiană cu skeologia coșeriană:

În mod cert, sensul lipsit de expresie, despre care am vorbit pînă acum, ne-ar putea îndemna [...] să ne întrebăm dacă nu cumva sensul în cauză cuprinde și 'sensul' în accepție coșeriană, în calitate de conținut al unui text / discurs, act concret de comunicare ș.a.m.d. (v. Munteanu, 2007, p. 40 și, în special, 2012a, p. 356), adică sensul care face obiectul hermeneuticii pe care Coşeriu a numit-o (încă din anii'50) lingüistica del texto. Se pare că nu (sau doar parțial). Nimic din cele afirmate de Hasdeu (și de Bréal) nu ne îndreptățește să susținem o asemenea ipoteză. Iar la Coșeriu obiectul lingvisticii textului și obiectul skeologiei lingvistice sînt bine delimitate. Aceasta nu înseamnă că cele două „obiecte” se exclud reciproc. Dimpotrivă. În realitatea complexă a vorbirii, sensul (unui text literar, bunăoară) nu se poate naște și nici nu poate fi revelat fără aportul cunoașterii 'lucrurilor' (și a opiniilor / ideilor despre 'lucruri'). După cum ne învață Coșeriu, într-un discurs / text sensul apare (sau este înțeles) datorită combinării semnificatelor de limbă cu desemnarea. Altfel spus (dat fiind faptul că limbajul este dublu semiotic), a vorbi, în acest caz, de un sens lipsit de expresie (adică de semnificant) nu ar fi în întregime corect, fiindcă semnificatele se convertesc, la un nivel superior, în „semnificantul” asociat sensului. În schimb, sensul lipsit de expresie / formă la care se referea Hasdeu reprezintă cunoașterea cu privire la 'lucruri', adică exact obiectul skeologiei coșeriene. (Munteanu, 2013, p. 92-93)

După cum se poate vedea, eram întrucîtva contrariat de faptul că Hasdeu (probabil, și din dorința de a rămîne fidel concepției lui Bréal) nu invocase și literatura ca loc de manifestare a „subînțelesurilor”, cu atît mai mult cu cît era chiar el autor de beletristică. De altminteri, cînd citisem prima dată studiul lui Hasdeu (mai sus menționat), îmi închipuisem că avem de-a face, pur și simplu, cu acel conținut lingvistic pe care Coșeriu (în cadrul distincției sale tripartite, desemnare - semnificație - sens) îl numise sens (v. Munteanu, 2007, p. 40 și 2012a, p. 356). Pînă și termenul noematologie mi se părea cam vag ori susceptibil de a fi întrebuințat și într-o altă accepție:

În încheiere, cîteva cuvinte și despre cei doi termeni, noematologie și skeologie. Este greu de hotărît care este mai potrivit. Observ, totuși, că termenul propus de Hasdeu poate induce „neinițiaţii” în eroare, pe de o parte, fiindcă gr. nóema denumea în vechime o figură de sens (deci, ne trimite iarăşi spre lingvistica textului); pe de altă parte, fiindcă în limba română există deja cuvîntul noimă (< ngr. nóima, urmaș al gr. nóema) a cărui semnificație ne duce cu gîndul tot la hermeneutică / lingvistica textului. (Munteanu, 2013, p. 93)

Descoperirea, pe cont propriu, a unui studiu scris de N.I. Apostolescu mi-a prilejuit un real sentiment de satisfacție, întrucît mi-a dovedit că felul în care înțelesesem, la întîia mea lectură, cele spuse de Hasdeu ar fi putut căpăta aprobarea lui Hasdeu însuși. Pînă să pornesc la drum pentru a demonstra ipoteza formulată, cred că se cuvine să facem cunoștință cu Nicolae I. Apostolescu. Consider că merită să prezint apoi și relația dintre el şi magistrul său. 


\section{Ultimul discipol al lui Hasdeu: Nicolae I. Apostolescu}

Nicolae I. Apostolescu (1876-1918) reprezintă azi o personalitate aproape uitată a culturii române. Născut la Alexandria, ajunge, odată cu mutarea întregii familii, la București (în 1891), unde își va continua studiile liceale și va urma Facultatea de Litere și Filosofie, obținînd (în 1899) licența în științe filologice (cu mențiunea magna cum laude). La universitatea bucureșteană i-a avut ca profesori pe B.P. Hasdeu, Titu Maiorescu, Gr. Tocilescu, Ion Bianu și alții. La 9 februarie 1899, este numit profesor secundar la Liceul „I.C. Brătianu” din Pitești, unde va rămîne pînă la sfîrșitul vieții. În 1905, luînd parte la un concurs inițiat de Ministerul Instrucțiunii Publice, cîștigă (din fondul „Iosif Niculescu”) o bursă de studii la Paris, pentru a urma cursuri de semantică și literatură comparată ${ }^{2}$. Sub îndrumarea lui Émile Faguet, își ia doctoratul în litere în 1909, la universitatea parisiană, cu două teze (publicate în Franța în același an): L'Influence des romantiques français sur la poésie roumaine și L'Ancienne versification roumaine. Este unul dintre primii comparatiști ai literaturii române și este recunoscut drept unul dintre cei mai buni specialiști ai noștri în problemele versificației. Deși era îndreptățit, prin activitatea și competența sa multilaterală, să primească o catedră universitară (în domeniul istoriei literaturii române și al esteticii literare), aceasta nu i-a fost încredințată decît în 1918, la Universitatea din Iași, cu puțină vreme înainte de a muri, pe neașteptate, din cauza unei pleurezii ${ }^{3}$. Figura și opera sa au fost scoase dintr-o relativă uitare mulțumită eforturilor lui Ion M. Dinu care, în 1983, a publicat atît o monografie despre Apostolescu, cît și o antologie conținînd unele studii și articole ale acestuia (v. Dinu, 1983 și Apostolescu, 1983).

Relația dintre Hasdeu și Apostolescu a fost una de un tip special din ambele direcții. Într-o scrisoare din 1904, Profesorul declara următoarele:

Din sutimi de elevi, în interval de vreo trei decenii din cariera mea universitară, cel mai nou ești dumneata, domnule Apostolescu, cel mai modest și totodată cel mai forte, și apoi mai puţin pasionat decît magistrul, căci mărturisesc eu însumi că am fost purure prea pasionat dar nu știu dacă pasiunea - o pasiune dezinteresată—este un viciu sau o virtute. Aproape de marginea vieții pămîntești, eu mă bucur că în privința întregei mele activități literare și științifice te las pe dumneata unicul meu urmaș direct: nimenea nu m-a înțeles mai bine, mai complet și mai controlat. (apud Dinu, 1983, p. 38)

După dispariția lui Hasdeu, Apostolescu i-a făcut acestuia un reușit portret literar (Hasdeu, în Apostolescu, 1983, p. 180-193; vezi și cap. VIII, Les Hasdeu, în Apostolescu, 1909, p. 331-397). Totuși, puternica influență pe care Magistrul a exercitat-o asupra elevului reiese cel mai bine, presupun, dintr-un paragraf care se află într-un portret dedicat lui... Delavrancea. În 1905, călătorind cu trăsura de la gara din Cîmpina spre „castelul” în care Hasdeu își trăia ultimii ani, Apostolescu este uimit să constate că în minte i s-au strecurat, în acele momente, cîteva reflecții despre literatura lui Barbu Ștefănescu-Delavrancea:

Citirea și răscitirea operelor lui Hasdeu m-au încredințat—și pe zi ce merge cred lucrul mai cu tărie—că omul acesta a fost un „cineva” de care trebuia să te apropii cu un respect aproape religios, și nu mă sfiesc să o spun: ori de cîte ori mi-a fost dat să-i vorbesc, să stau împreună cu el cîteva ceasuri ori cîteva zile, sau chiar numai cînd l-aș fi zărit, simțeam o adîncă și supremă emoție. E

\footnotetext{
${ }^{2}$ Ion M. Dinu, cel mai bun cunoscător al vieții și operei lui Apostolescu, precizează că ar fi fost vorba de cursuri de „Semantică, Noematologie [sic!] și literatură comparată” (v. Dinu, 1983, p. 5), dar nu ni se spune de unde are această informație. În rest (vezi, de pildă, Faifer, 2004, p. 206 și chiar I. M. Dinu, în prefața la Apostolescu, 1983, p. 6), nu se menționează decît cursurile de semantică și de literatură comparată. La Paris nu se făceau, în nici un caz, cursuri de noematologie; deci, trebuie să fi fost, la mijloc, recomandarea lui Hasdeu sau a cuiva care știa că, încă din 1900, Apostolescu discutase despre noematologie.

${ }^{3}$ Pentru mai multe detalii despre viața și opera lui N. I. Apostolescu, vezi, în special, Dinu, 1983.

${ }^{4}$ Scrisoarea este datată la 9 august 1904 (cf. și prefața lui I. M. Dinu la Apostolescu, 1983, p. 9). Nicolae I. Apostolescu o va reproduce în „precuvîntarea” la volumul său de studii din 1904, alături de recomandările făcute de Gr. Tocilescu şi de G. Ionescu Gion.
} 
de închipuit dar mirarea, uimirea care m-a cuprins ca în minutele cînd mintea întreagă mi-era stăpînită de personalitatea cea măreață a lui Hasdeu să mai găsesc un loc pentru un alt scriitor, ba încă să cuget cîteva minute-cum mi s-a întîmplat—la frumusețea expresiilor din operele d-lui Delavrancea. (Delavrancea, în Apostolescu, 1983, p. 283)

\section{Limbajul și înfăţișările lui sociale}

După aceste considerații mai mult sau mai puțin introductive, însă neîndoielnic necesare, avem acum libertatea deplină de a examina pe îndelete contribuția autorului nostru.

Studiul Limbajulși înfățtş̧ările lui sociale (reluat și în Apostolescu, 1983, p. 86-144) a fost, într-o primă formă, o conferință intitulată Despre cuvînt (ținută, la 14 mai 1900, la „Societatea istorică a studenților în litere”), apărînd (cu acest titlu) atît în revista „Tinerimea română” (serie nouă, vol. IV, fasc. 1-2) și ca extras (în broșură ${ }^{6}$ ) în același an. Apostolescu o va include (cu minime adăugiri) într-o antologie a propriilor lucrări, Studii. Literatură, estetică, fllologie (Institutul de arte grafice „Eminescu”, București, 1904, p. 99-137) ${ }^{7}$. Limbajul și înfățţ̧̦ările lui sociale conține secțiunile: Originea limbajului după diferiți cugetători; Graiul și arta; Ideile latente - noematologia; Semasiologie și noematologie; Corupția fonetică; Numele proprii; Legea regresiunii memoriei - derivarea părților de cuvînt.

Judecat în ansamblul său, materialul de care ne ocupăm este-cu unele excepții notabile (între care şi chestiunea noematologiei) - lipsit de originalitate, mai ales în privința faptelor lingvistice vehiculate, lucru explicabil, dacă ne gîndim că a fost destinat, în primul rînd, studenților în litere de la „Societatea istorică”. Așadar, „studiul” aduce, mai curînd, cu un curs universitar în care Apostolescu, folosindu-se din abundență de citate preluate de la autoritățile în domeniu și rezumînd diverse concepții, înfățișează o serie de aspecte esențiale ale limbajului omenesc. Setea de cunoaștere a acestui profesor de liceu trebuie să fi fost extraordinară, fiindcă nu se mulțumește să menționeze doar părerile lingviștilor și ale filologilor (A.H. Sayce, Max Müller, M. Bréal, A. Darmesteter, W.D. Whitney, B. P. Hasdeu, A. Lambrior, L. Șăineanu, A. Philippide, O. Densusianu etc.), ci se referă și la naturaliști (printre care Ch. Darwin, desigur), istorici, sociologi, filosofi ș.a.m.d. Nu lipsesc nici trimiterile la scriitori (Lucretius, Anatole France, B. Șt.Delavrancea) sau specialiști în estetică și literatură (cum este C. Martha, de pildă).

Încă de la început, Apostolescu insistă asupra caracterului social al limbii. Impresionează, totodată, atenția pe care conferențiarul o acordă, de la primele pagini, raportului dintre limbaj și artă (în secțiunea Graiul şi arta): „Cu nici o altă manifestare socială nu e în mai strînsă legătură vorbirea decît cu arta, cu care unii o și confundă sau cel puțin o împreună în mai multe puncte” (Apostolescu, 1983, p. 91) . Faptul că autorul nostru, discutînd teme lingvistice, are în minte în permanență (datorită înclinațiilor și a pregătirii sale) dimensiunea artei în general și a literaturii în special îşi va dovedi însemnătatea la un anumit moment al expunerii. Firește, nu îmi propun să prezint și să comentez aici conținutul integral al „studiului”. Consemnarea principalelor teme tratate este de ajuns. Fără îndoială, unele idei ale științei lingvistice de atunci nu mai pot fi susținute astăzi, dar nu evidențierea acestora m-a interesat, ci scoaterea în relief a intuițiilor excelente pe care Apostolescu le-a avut cu privire la aria de cuprindere a noematologiei. Iată de ce voi analiza, în cele ce urmează, cu precădere, paginile din cele două secțiuni rezervate acestei discipline: Ideile latente - noematologia și Semasiologie și noematologie. Chiar și (numai) așa, trebuie precizat că cele două secțiuni constituie aproape o treime din spațiul întregii lucrări. Ba chiar se mai pot

\footnotetext{
${ }^{5}$ Ion M. Dinu (1983, p. 58) notează că s-ar fi publicat (iarăși?) tot în „Tinerimea română”, vol. VI, fasc. 1-2, în schița Gr. Tocilescu, Istoria românilor. $\mathrm{Nu}$ am putut verifica dacă este vorba despre o completare sau o continuare a primei versiuni.

${ }^{6}$ Scoasă la Tipografia „Corpului didactic C. Ispășescu și G. Brătănescu”, București, 1900 [totalizînd 36 p.].

${ }^{7}$ Pentru acest volum, Nicolae I. Apostolescu va primi și „Premiul Adamachi” (în valoare de 500 de lei) al Academiei Române pe anul 1904 (v. Bianu, 1905, p. 319). În raportul său favorabil, N. Quintescu considera studiul Limbajul și înfățişările lui sociale ca fiind „cel mai important din punctul de vedere științific” din întreaga carte (Quintescu, 1905, p. 423).

${ }^{8}$ Într-adevăr, este suficient să mergem la Estetica lui Benedetto Croce (apărută în 1902), pentru a ne convinge că o atare opinie era curentă în acea epocă.
} 
adăuga și cîteva paragrafe (Apostolescu, 1983, p. 119, 123 și 127) din secțiunea Corupțtia fonetică, în care Apostolescu explică unele mutații semantice tot cu ajutorul sensurilor latente.

\section{Cu Hasdeu dincolo de Hasdeu}

În ce constă, în definitiv, contribuția lui N. I. Apostolescu? Prin ce anume îl depășește el pe Hasdeu cînd vine vorba de noematologie? Aș spune că Apostolescu are cel puțin două merite în această privință: (1) faptul de a fi legat problema subînțelegerii, așa cum a formulat-o Hasdeu, și de artă (sau de literatură, mai cu seamă); (2) faptul de a fi utilizat noematologia și noțiunea de 'idee latentă' în mod explicit în discuțiile de natură etimologică. În afara acestora, Apostolescu a mai făcut unele observații despre planul 'sensului' a căror importanță o voi sublinia la locul cuvenit.

Să ne reamintim că, pregătind propunerea referitoare la doctrina noematologiei, Hasdeu afirmă următoarele: „Graiul este un mijloc de înțelegere mutuală. O înțelegere mutuală se operă nu numai prin sensul cel expres care constituie obiectul semasiologiei, ci mai mult încă printr-un sens ascuns, lăsat fără expresiune, subînțeles, care se manifestă mai cu deosebire în sintaxă” (Hasdeu, 2013, p. 130). Sensul neexprimat, pe care insistă Hasdeu, este—o zice chiar el imediat—,ideea latentă” teoretizată de Bréal. Apostolescu știe prea bine lucrurile acestea, fiindcă citează din (și face trimitere la) ambele studii: cel al lui Hasdeu din 1882 (despre diviziunile gramaticii comparative) și cel al lui Bréal, Les idées latentes du langage

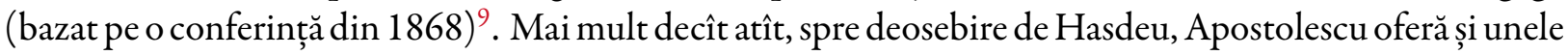
exemple românești (pe lîngă o serie de ilustrări franțuzești preluate de la Bréal) „pentru a lămuri și mai bine importanța acestei doctrine a noematologiei”: „Dar în românește sufixul -ie are aceeași valoare în pescărie de la pescar și în olărie de la olar? Aci numai ideile latente pot explica rostul acestor sufixe. Trebuie să avem, zice Bréal, o subînțelegere a unor relații de natură concretă și de o speță particulară, pe care mintea noastră le ghicește mai mult decît le vede în vorbele exprimate” (Apostolescu, 1983, p. 103). După cum am arătat (v. Munteanu, 2013), «ideile latente» fac și obiectul skeologiei propuse de Coșeriu. Numai că nu tot ce ține de noematologia hasdeiană redimensionată / reconfigurată de Apostolescu aparține skeologiei coșeriene. O porțiune a noematologiei-așa cum (repet!) o vede Apostolescu-aparține, mai degrabă, hermeneuticii. Cum se susține o asemenea aserțiune? Voi încerca să răspund în continuare.

În secțiunea intitulată chiar Ideile latente - noematologia, pînă să vorbească despre ideile latente ale lui Bréal și de noematologia lui Hasdeu, Apostolescu pornește nu de la limbaj, ci de la artă în general. Și acultătorului, și privitorului, și cititorului-spune el dintru început—artistul trebuie să le ofere posibilitatea („să [le] lase deschise porțile și să [le] întindă punți”) de a descoperi, „prin asocieri de idei, părțile subînțelese”: „E o anumită discreție pe care trebuie să o posede oricare artă și un anumit substrat, un subînțeles pe care trebuie să-l aibă orice cuvînt” (Apostolescu, 1983, p. 101). Mai departe, el expune unele idei și exemple luate îndeosebi din cartea lui Constant Martha, La délicatesse dans l'art (1884, ed. I), din capitolul La discrétion dans l'art et les sous-entendus (Apostolescu, 1983, p. 101-102). Martha inventariază diverse cazuri (din pictură, din literatură, din muzică, dar și din viața de toate zilele) în care acționează forța sugestiei, în care, grație unor asocieri de idei, ni se deșteaptă subînțelesuri: un chip îngrozit, o floare uscată, sunetul clopotului, mirosul fînului cosit sau al unui parfum etc. pot declanşa o adevărată iluminare în conștiința celor care le experimentează prin simțuri. În plan discursiv („în vorbire”), generatoare de subînțelesuri sînt și metafora, simbolul, alegoria, hiperbola, ironia ș.a.m.d. (Apostolescu, 1983, p. 102).

Rezumînd unele paragrafe din volumul lui C. Martha (la care, de altminteri, trimite foarte exact în subsolul paginilor), Apostolescu dă impresia, la o privire neatentă, că traduce mot-á-mot din franceză. Și totuşi... Reproduc, în paralel, două citate (din originalul lui Martha şi din sinteza lui Apostolescu):

( $\alpha$ ) „L'art d'écrire n'est le plus souvent que l'art de suggérer d'idées et de sentiments qu'on n'en exprime. [...] Tantôt par une image, tantôt par un seul mot ils nous découvrent un monde" (Martha, 1907, p. 115$)^{10}$.

\footnotetext{
${ }^{9}$ Pentru o analiză a lucrării lui M. Bréal (1868/1882), vezi și studiul meu introductiv la Hasdeu, 2013, p. 70-74.

${ }^{10}$ Edițiile ulterioare ale cărții lui C. Martha sînt, de fapt, retipăriri ale ediției princeps din 1884 . Am consultat ediția a IV-a,
} 
( $\beta$ ) „Arta de a scrie ca și arta de a vorbi nu sînt de cele mai multe ori decît arta de a sugera idei și sentimente, neexprimate, dar subințtelese [subl. mea, C.M.]. Adesea printr-o singură vorbă, printr-o imagine ni se descopere [sic!] o lume întreagă" (Apostolescu, 1983, p. 102).

Se observă lesne că Apostolescu (în „traducere” / rezumat) a adăugat de la sine cuvintele „arta de a vorbi” şi „dar subînțelese”, nu doar pentru a completa cele spuse de Martha, ci pentru a pregăti terenul discuției referitoare la ideile latente și la noematologie, intenție care se vădește și din inversiunea realizată, menită să deplaseze accentul de pe imagine pe cuvînt (să se compare structura „printr-o singură vorbă, printr-o imagine” cu orig. fr. „tantôt par une image, tantôt par un seul mot”). Într-adevăr, imediat după aceasta, Apostolescu apelează la Bréal și la Hasdeu, iar discuția ia o turnură preponderent lingvistică, chiar dacă paralela artă - limbaj continuă să se mențină: „Ca și în artă, în vorbire ideile acestea latente, subînțelese sînt o condiție necesară a progresului cugetării omenești” (Apostolescu, 1983, p. 102-103) ${ }^{11}$.

Astfel, cu subtilitate (după cum vom vedea și ceva mai încolo), Apostolescu lărgește sfera noematologiei, incluzînd printre ideile (sau sensurile) latente și sensurile operelor artistice (cu precădere cele ale textelor literare). Bun cunoscător al operei lui Hasdeu și pasionat de literatură, nu se putea ca el să nu lege în mod fericit sensul ,ascuns, lăsat fără expresiune, subînțeles” (v. supra) de sensul operei de artă, cu atît mai mult cu cît considera (contrar unor teorii actuale) că arta, ca şi limbajul, este un fenomen social. De altfel, cu cîteva pagini înainte, în secțiunea Graiul și arta, autorul îşi anunța obiectivele:

Dacă graiul e social, cu atît mai mult ni se prezintă arta ca atare [...]. Cercetînd paralel unele manifestări ale artei și ale vorbirii, se va lămuri și mai bine această asemănare a celor două fenomene psihice în modul lor de producere ori de exprimare. Putinţa sau imposibilitatea artistului sau a unui simplu vorbitor de a exprima tot ceea ce simte, tot ceea ce vrea-e punctul în jurul căruia se vor grupa elementele acestei discuții. (Apostolescu, 1983, p. 93; cf. și p. 98-100)

Mutînd analiza pe terenul limbii, Apostolescu se oprește la „unul din cele mai frumoase exemple de evoluare a unui cuvînt graţie sensurilor latente”. Este vorba despre felul în care mulţumesc, provenind din urarea „la mulți ani”, a ajuns să însemne ceea ce înseamnă azi (după ce și-a modificat forma fonetică, se pare, și sub influența lui mulțime):

Trecerea de la un sens la altul s-a făcut grație subînțelesului. Zicîndu-i-se cuiva: „să trăiești mulți ani”, cu vremea lumea s-a gîndit că era numai o mulțumire, un răspuns la o salutare; s-a gîndit adică numai la ideea subînțeleasă, nu la cea exprimată. Cu timpul, sensul latent a luat locul celui exprimat—probabil totodată și cu schimbarea fonetică al cărei rezultat a fost contopirea ambelor cuvinte într-unul. (Apostolescu, 1983, p. 104) ${ }^{12}$

Acest exemplu și cele care urmează în secțiunea Semasiologie şi noematologie conturează foarte adecvat obiectul noematologiei ca skeologie lingvistică. Reamintesc că, pentru Coșeriu, skeologia are ca sarcină cercetarea contribuției cunoașterii 'lucrurilor' (și a opiniilor sau credințelor despre 'lucruri') la vorbire. Or, tocmai aceste aspecte dorește să le pună în lumină și Apostolescu, reinterpretînd în grilă noematologicădacă pot spune aşa-cîteva dintre investigațiile etimologice ale lui Hasdeu, pe care savantul le publicase în „Columna lui Traian” la scurt timp după ce tratase (în aceeași publicaţie) chestiunea noematologiei. Este surprinzător însă că în respectivele articole—Șugubăț și șugubină (1882), Creștet și urzică (1882), Scornesc

din 1907. Apostolescu face trimitere, în studiul său, la o ediție din 1897, iar apoi, în teza sa de doctorat, utilizează chiar prima ediție (v. Apostolescu, 1909, p. 4).

${ }^{11}$ Apostolescu trimite, într-o notă de subsol, la studiul lui Bréal. Nici la pagina indicată, dar nici în restul lucrării lingvistului francez, nu găsim, desigur, vreo referire la artă. La fel, nici C. Martha nu-l menţionează pe M. Bréal în vreun loc din cartea sa.

${ }^{12}$ Apostolescu citează frecvent și din lucrările lui Șăineanu. În Semasiologia acestuia se mai găsește un exemplu similar care ar fi meritat amintit: „Bogdaproste sau bodaproste 'Dumnezeu să vă ierte (păcatele)', formulă de mulțumire a cerșetorilor, care, mereu repetată, devine o monotonă flecărie, de unde locuțiunea: a umplea [sic!] pe cineva de bogdaprosti 'a-l ameți cu gura.'” (Șăineanu, 1999, p. 194). 
și stîrnesc (1883) (v. Hasdeu, 1988, II)_Hasdeu nu apelează nici măcar o dată la conceptele (sau termenii) de 'idee latentă ori 'noematologie'13. În consecință, demersul lui Apostolescu este cu atît mai lăudabil.

Printre altele, el caută să arate (amestecînd propriile observații cu explicațiile lui Hasdeu) „cum partea semantică și partea noematologică” au condus la semnificația actuală a cuvîntului șugubină. Cred că este instructiv să vedem cum procedează. Din sl. șugubina, însemnînd inițial în paleoslavă 'pierdere de suflet', termenul a intrat în românește cu sensul de 'legătură sexuală ilicită, „orice relație nelegitimă între bărbat și femeie fiind considerată 'pierdere de suflet', din punctul de vedere al canoanelor bisericești”' (Apostolescu, 1983, p. 105). Prin metateză, duşegubină > deşugubină, ceea ce a urmat explicîndu-se printr-o „dublă etimologie poporană”, deoarece s-a crezut: „1) că avem a face cu două cuvinte, din care primul e prepoziția de iar al doilea, şugubină; 2) că vorba şugubină — proprie în acest fel numai limbii române-înseamnă 'mauvaise plaisanterie', belea, întîmplare ciudată' (Apostolescu, 1983, p. 105). Pentru a aduce discuția în sfera noematologiei, Apostolescu reformulează analiza lui Hasdeu astfel:

Duşegubina era în vechea legislație română o 'legătură sexuală nepermisă, iar în genere poporul da acest nume 'crimei', după cum rezultă din textele citate de Hasdeu în studiul său. Cel care făcea o asemenea faptă nepermisă trebuia să plătească, să dea o despăgubire. A plăti duşegubina-mai apoi de șugubina - adică a plăti crima, păcatul, ca o răscumpărare, a luat în mintea poporului înțelesul de 'a plăti o amendă', 'a da o plată', cu alte cuvinte duşegubina sau de șugubina a luat însemnarea de 'amendă', 'despăgubire'. Aci intervine ideea latentă: a plăti o amendă însemna 'a da de o belea'. Aceasta era ideea subînțeleasă, care, ajutată și de forma de exprimare „a da dușegubină”, schimbată cu vremea în „a da de șugubină”, folosindu-se și de etimologia poporană care alătura cuvîntul nostru de șuguesc, ne-a dat sensul actual de 'mauvaise plaisanterie', belea, întîmplare rea. (Apostolescu, 1983, p. 105-106)

Într-adevăr, numeroase asemenea cazuri de „combinare de fenomene semasiologice și noematologice” (după cum le caracterizează Apostolescu) ar putea fi invocate. Este destul să pătrundem în domeniul frazeologiei, cercetînd originea unor expresii ca a-și aprinde paie-n cap (cf. Șăineanu, 1999, p. 232-234 și Dumistrăcel, 2001, p. 294-295), a da bir cu fugiții (cf. Dumistrăcel, 2001, p. 46) și altele, pentru a întrevedea posibilele foloase pe care le-ar aduce noematologia, aplicînd „rețeta” lui Apostolescu.

Discipolul lui Hasdeu, stimulat de lucrările acestuia, Creștet și urzică și Scornesc și stîrnesc, se arată interesat îndeosebi de etimologia populară, încercînd să determine în ce constă mecanismul mental prin care se produce o atare transformare:

Un lucru mai rezultă din analiza procedeului urmat de popor în mînuirea etimologiei acesteia proprie lui: el atribuie noțiunii-cuvînt niște note pe care vorba nu le posedă, nemulțumit cu sensul prea vag, prea nelămurit pe care îl prinde la prima dată. Dorind să-şi explice originea și înrudirile cuvîntului-pe care n-are putința a le cunoaște în mod științific-el îi atribuie o descendență oarecare, bazîndu-se de obicei pe o întîmplătoare asemănare fonetică. (Apostolescu, 1983, p. 107)

\section{Noematologie și hermeneutică}

Ceea ce găsim în continuare în discursul lui N. I. Apostolescu mi se pare foarte important, fie și ca intuiţie:

Această tendință pe care o are poporul de a-și satisface curiozitatea etimologică se întinde de la un singur cuvînt la o bucată literară întreagă. Unui cuvînt i se caută semnificarea și originea de către

\footnotetext{
${ }^{13}$ De altfel, nu am găsit nici o altă lucrare în care Hasdeu să fi întrebuințat ulterior cele două noțiuni. Cît despre ideologic (utilizat în sintagme precum „ciocnire ideologică” ș.a.m.d.) sau ideologie, acestea se datorează influenței lui Schleicher, neînsemnând altceva decît 'semantic' (ori 'semasiologic'), respectiv 'semantică' (ori 'semasiologie').
} 
oricine: de primul vorbitor în feluritele ocazii care i se prezintă în viață la pronunțarea acelei vorbe sau la citirea ei. Cel care va avea însă și o cultură literară va căuta-în mare-să prindă cît mai bine sensul unui vers, unei poeme, unui roman, unei drame, unei doctrine filosofice. (Apostolescu, 1983, p. 107-108)

De ce cred că Apostolescu rostește ceva de mare însemnătate aici? Pentru că dovedește ceea ce s-ar putea numi „atitudine hermeneutică”. El intuiește faptul că „totul este interpretare”. Hans-Georg Gadamer (2001, p. 714-715) s-ar fi referit în acest caz la „universalitatea hermeneuticii”. Interpretăm nu doar texte, ci și situații prezente ori istorice. Și facem acest lucru cu ajutorul limbajului exprimat (exteriorizat) sau numai gîndit (cf. Munteanu, 2019, p. 38). Nici nu are relevanță mereu dacă rezultatul interpretării este unul adevărat ori fals. În oceanul de sensuri în care trăim, „adevărurile” verificabile științific nu reprezintă decît o insulă (v. Dewey, 1963, p. 4-5).

Printre rîndurile dedicate chestiunilor lingvistice, conform obiceiului său, Apostolescu inserează și alte meditații legate de literatură. Vorbind despre sensul unei opere (fie aceasta dramă, poezie sau doctrină filosofică), el afirmă:

Se va întîmpla însă, de cele mai multe ori, ca să o socotească ca pe o canava necomplet brodată, in care el va pune, peste tot, idei de ale lui. Astfel, această lucrare se va prezenta minții a o sută de indivizi în o sută de feluri, după punctul de vedere din care a privit-o, a completat-o, a priceput-o fiecare. [...] Și lucrul acesta este explicabil. Chiar fără a căuta sensul mai adînc al unei bucăți literare sau fără a dori găsirea etimologiei unui cuvînt, oricine va fi încurcat cînd i se va cere lămurirea notelor unei noțiuni. (Apostolescu, 1983, p. 108)

Hermeneutica sensului, așa cum a teoretizat-o Eugeniu Coșeriu, are ca obiect revelarea sistematică și justificată a conţinutului unui text sau al unui discurs. Cînd are în vedere „sensul mai adînc al unei bucăţi literare” ori „sensul unui vers, unei poeme, unui roman, unei drame, unei doctrine filosofice”, Apostolescu se apropie foarte mult de accepția pe care o dă Coșeriu sensului. Cum se face însă că autorul nostru stabilește o relație analogică între ceea ce urmărește într-un text un critic literar, de pildă, și ceea ce caută un simplu vorbitor cu privire la originea unui cuvînt sau a unei expresii?

Pentru a arăta în ce măsură este îndreptățită analogia lui Apostolescu, voi da un exemplu din frazeologie. Expresia a-și aprinde paie în cap desemna acțiunea prin care, după tipicul oriental, se făcea o reclamație, adică i se atrăgea atenția unui demnitar cu privire la o anumită nedreptate prin purtarea, deasupra capului, a unei rogojini aprinse. Dar acțiunea în cauză se putea întoarce împotriva reclamantului: „De la a atrage luarea aminte asupra unei nemulțumiri sau plîngeri pînă la a întărîta pe cineva din pricina acestei jeluiridistanța nu-i mare" (Șăineanu, 1999, p. 234). Cum de și-a schimbat semnificaţia această expresie? În nici un caz prin metaforă! Vorbitorul a evaluat o situație desemnată, de regulă, prin sintagma respectivă și a ajuns la concluzia (bazată pe cunoașterea „lucrurilor”) că „a-și aprinde paie-n cap” în vremurile acelea a ajuns să însemne altceva decît se credea (ori se spera) inițial. Altfel spus, simplul vorbitor a prins tîlcul unei situații (repetabile), a avut o iluminare asemănătoare celei care îl încearcă pe cineva care a priceput o glumă („,s-a prins de poantă”, cum se zice) sau celei pe care o experimentează un critic literar care a înțeles o poezie dificilă. Cînd Apostolescu se referă la acea „combinare de fenomene semasiologice și noematologice”, ne dăm seama că avem de-a face, la rigoare, cu o combinare a semnificației cu desemnarea. Așa ne spune Coșeriu că ia naştere sensul unui text. Fie și numai în minte (ca discurs interior), așa se produce și sensul unei situații interpretate (gîndite lingvistic).

Firește, interpretările pot cunoaște diverse grade de științificitate. Vorbitorul, în naivitatea sa, poate greși atunci cînd vrea să-și explice, bunăoară, originea unui cuvînt. Astfel apar, într-adevăr, cazurile de etimologie populară. Bun sau rău, „sensul înhățat” ${ }^{\prime 1}$ de vorbitor reprezintă o explicaţie (or, una dintre accepțiile termenului hermeneia, din greaca veche, era chiar aceea de 'explicație'). Și, după cum observă

\footnotetext{
${ }^{14}$ John Dewey definește adesea chiar așa procesul înțelegerii: „to understand is to grasp meaning”.
} 
Apostolescu, la fel i se poate întîmpla și celui care caută „sensul adînc” al unei opere literare. Astăzi am zice că literatura este spațiul în care interpretările eronate („decodările aberante”, după U. Eco) se întîlnesc cel mai frecvent (v. Munteanu, 2012b).

Pornind de la studiile sau cărțile lingviștilor preferați, N.I. Apostolescu oferă şi alte exemple de evoluții semantice prin care sensurile latente, motivate de condiții istorice specifice, au înlocuit semnificațiile proprii ale unor cuvinte. Poate că nu întotdeauna justificările sale (apelînd la logica lui John Stuart Mill, de pildă) sînt cele mai potrivite. Pe alocuri, el pare că face confuzie între (ceea ce numim astăzi) lexic comun şi lexic specializat (sau terminologie), deși intuiția de la care pleacă nu este în sine greșită (cf. și Munteanu, 2011b). Însă modul (agreat de Hasdeu) în care dezvoltă și duce mai departe cele deprinse de la magistrul său mi se pare impresionant. Pentru aceasta, Apostolescu merită întreaga noastră prețuire.

\section{7. În loc de concluzii}

În încheiere, aș atrage atenția asupra unui exemplu tipic de... receptare defectuoasă a unei teorii inedite, cum este și proiectul noematologic inițiat de B.P. Hasdeu și rafinat de Nicolae I. Apostolescu. Iată comentariile, lipsite de înțelegere și de viziune, făcute de un contemporan al lui Apostolescu, un oarecare D. M., indignat că elevul lui Hasdeu fusese recompensat pentru meritele sale cu o bursă din fondul „Iosif Niculescu” (ca să studieze la Paris):

Obiectul burselor este uneori ridicol. Astfel la 1905 s-a acordat o bursă pentru semasiologie și noematologie. Mai întîi noematologie este un termin prin care Hasdeu înțelegea tocmai ceea ce noi iștialalți înțelegem prin semasiologie. Semasiologie și noematologie însamnă deci semasiologie și semasiologie. Apoi, semasiologia este un infim fragment din istoria unei limbi și n-a ajuns încă a se constitui ca disciplină aparte—sînt chiar filologi care contestă posibilitatea stabilirei unei științi semasiologice. Din această cauză la nici o universitate din lume nu există catedră specială pentru semasiologie, și nici un filolog din lume nu s-a gîndit să facă din semasiologie obiectul preocupărilor sale exclusive. (D.M., 1910, p. 343)

$\mathrm{Nu}$ are rost să zăbovim asupra acestor cuvinte. Așa vor fi gîndit și alții în epoca respectivă. Pentru N.I. Apostolescu, mai importantă va fi fost, desigur, judecata confirmatoare a lui Hasdeu (cunoscut pentru excepționala sa intuiție în privința valorilor ${ }^{15}$ ), precum și conștiința faptului că lucra la consolidarea unui domeniu nou. Din păcate, destinul nefavorabil nu i-a îngăduit să-și desăvîrșească opera în timpul vieții. Însă ideile sale bune pot fi recuperate și valorificate de către posteritate. În acest punct, mi se pare nimerit să reproduc citteva reflecții personale din anul 2015, cînd aveam în vedere (printre altele) și exemplul noematologiei:

O descoperire culturală nu este, totuși, similară uneia de tip geografic. Chiar uitată fiind, ea poate fi redescoperită, (re)pusă în circulație și fructificată. Există istorii ale lingvisticii (sau ale ideilor lingvistice) ce ignoră acele teorii izolate (dar sclipitoare) care nu au avut vreo influență asupra dezvoltării ulterioare a științei în cauză. De asemenea, există și cercetători care-și închipuie că disciplina lor începe odată cu ei şi nu se preocupă de contribuțiile înaintașilor (măcar pentru a le menționa, chiar dacă rezultatele cu pricina nu li se par complet satisfăcătoare). Există, totodată, idei sau intuiții excelente ale unor oameni de știință geniali care apar prea devreme, în sensul că nu pot fi (încă) pricepute de contemporani, avînd nevoie de venirea unor timpuri mai prielnice. Și, tot așa, există și teorii bine întemeiate, care, din păcate, au avut neșansa să se ivească

\footnotetext{
${ }^{15}$ În acest sens, mă mulțumesc să amintesc aici un singur caz (dintre cele remarcate de Cicerone Poghirc în monografia dedicată lui Hasdeu): „[...] I.A. Baudouin de Courtenay, al cărui nume apare frecvent și cu care el a întreținut de asemenea corespondență și legături prietenești, a fost, am putea spune, «descoperit» pentru știința europeană de B.P. Hasdeu, care i-a prevăzut de la primele lucrări o carieră strălucită, ce avea să fie confirmată mai tîrziu de aprecierile lui Ferdinand de Saussure” (Poghirc, 1968, p. 77).
} 
în contextul în care tocmai se schimbau «módele» (și nu neapărat «paradigmele») în știinţă, fiind considerate, în consecință, «depășite». De ce nu este o descoperire culturală similară (pe de-a-ntregul) uneia geografice, chiar și atunci cînd trece (o vreme) neobservată? Fiindcă, spre deosebire de cea geografică, ea conține deja unele sensuri, propriile sensuri. Acestea pot fi reluate, verificate și multiplicate. (Munteanu, 2015, p. 68).

\section{Bibliografie}

Apostolescu, N. I. (1909). L'Influence des romantiques français sur la poésie roumaine, avec une Préface de Émile Faguet, Librairie Ancienne Honoré Champion, Paris.

Apostolescu, N. I. (1983). Studii și portrete literare, ediție îngrijită și prefață de Ion M. Dinu, Editura Dacia, Cluj-Napoca.

Bianu, I. (1905). Raport general asupra lucrărilor prezentate la concursul premiilor anuale din 1904: Marele Premiu Năsturel, Eliade-Rădulescu și Adamachi, în „Analele Academiei Române”, Partea Administrativă și Desbaterile, Seria II, Tomul XXVII, 1904-1905, Institutul de Arte Grafice „Carol Göbl” S-sor Ion St. Rasidescu, București, p. 313-327.

Bréal, M. (1868/1882). Les idées latentes du langage [prelegere din 1868], în Michel Bréal, Mélanges de mythologie et de linguistique, deuxième édition, Librairie Hachette et $\mathrm{C}^{\text {ie }}$, Paris, 1882, p. 295-322.

Dewey, J. (1963). Philosophy and Civilization, Capricorn Books, New York.

Dinu, I.M. (1983). Nicolae I. Apostolescu. Omul și opera, Editura Scrisul Românesc, Craiova.

D. M. = (1910), [recenzie la] Victor Atanasiu, Monografia fondurilor Răducanu Simonidi și Iosif Niculescu, București, GöblRasidescu, 1909, 1 vol. în 8 mic de 277 pagini, färă preț, în „Viața romînească, V (11), p. 342-344.

Dumistrăcel, S. (2001). Pînă-n pînzele albe. Expresii românești (ediţia a II-a revăzută și augmentată), Editura Institutul European, Iași.

Faifer, F. (2004). Apostolescu, N. I., articol în [Academia Română] Dicționarul general al literaturii române (coord. gen.: Eugen Simion), vol. I (A-B), Editura Univers Enciclopedic, București, p. 206-207.

Gadamer, H.-G. (2001). Adevărși metodă, traducere de Gabriel Cercel şi Larisa Dumitru, Gabriel Kohn, Călin Petcana, Editura Teora, București.

Hasdeu, B. P. (1988). Studii de lingvistică și filologie, vol. I și II, ediție îngrijită, studiu introductiv și note de Grigore Brâncuș, Editura Minerva, București.

Hasdeu, B.P. (2013). Studii de știința limbii, prologul editorului, studiu introductiv și note de Cristinel Munteanu, Editura Institutul European, Iași.

Husserl, E. (2011). Idei privitoare la o fenomenologie pură și la o filozofie fenomenologică. Cartea întâi: Introducere generală în fenomenologia pură, traducere din germană de Christian Ferencz-Flatz, Editura Humanitas, București.

Martha, C. (1907). La délicatesse dans l'art [1884], quatrième édition, Librairie Hachette et C ${ }^{\text {ie }}$, Paris.

Moroianu, C. \& Munteanu, C. (2016). Sur la polygenèse dans la terminologie linguistique: paronymes et homonymes terminologiques, în „Revue roumaine de linguistique”, LXI, no. 2, p. 207-220.

Munteanu, C. (2007). Sinonimia frazeologică în limba română din perspectiva lingvisticii integrale, Editura „Independența Economică”, Pitești.

Munteanu, C. (2011a). Cînd Coșeriu (pare că) greșește, în „Analele Universității «Dunărea de Jos» din Galați”, fascicula XXIV, IV (2), Lexic comun / Lexic specializat, Editura Europlus, Galați, p. 26-50.

Munteanu, C. (2011b). Despre necesitatea implicării skeologiei lingvistice în socioterminologie (cu o privire specială asupra sintagmei „apă minerală”), în „Analele Universității «Dunărea de Jos» din Galați”, fascicula XXIV, IV (2), Lexic comun / Lexic specializat, Editura Europlus, Galați, p. 219-230.

Munteanu, C. (2012a). Lingvistica integrală coșeriană. Teorie, aplicaţii și interviuri, Editura Universității „Alexandru Ioan Cuza”, Iași.

Munteanu, C. (2012b). Aberrant Decoding and Its Linguistic Expression (An Attempt to Restore the Original Concept), in „Procedia - Social and Behavioral Sciences", vol. 63, p. 229-241.

Munteanu, C. (2013). Noematologia lui B. P. Hasdeu: o anticipare a skeologiei lui E. Coşeriu, în „Philologica Jassyensia”, IX (2), p. $85-94$.

Munteanu, C. (2015). Cîteva metafore privind valoarea descoperirilor și puterea tradiției în știință, în „Limba română” (Chișinău), XXV (1-2), p. 62-70.

Munteanu, C. (2019).John Dewey și problema sensului. Premise pentru constituirea unei hermeneutici integrale, Editura Universității „Alexandru Ioan Cuza”, Iași.

Poghirc, C. (1968), B. P. Hasdeu. Lingvist și filolog, Editura Științifică, București.

Quintescu, N. (1905), Raport [privitor la N.I. Apostolescu, Studii, București, 1904], în „Analele Academiei Române”, Partea Administrativă și Desbaterile, Seria II, Tomul XXVII, 1904-1905, Institutul de Arte Grafice „Carol Göbl” S-sor Ion St. Rasidescu, București, p. 420-423. 
Rother, C. (2005). Der Ort der Bedeutung. Zur Metaphorizität des Verhältnisses von Bewußtsein und Gegenständlichkeit in der Phänomenologie Edmund Husserls, Verlag Dr. Kovac, Hamburg.

Șăineanu, L. (1999). Incercare asupra semasiologiei limbei române. Studii istorice despre tranzițiunea sensurilor [1887], ediție îngrijită, studiu introductiv și indice de Livia Vasiluță, Editura de Vest, Timișoara. 